\title{
ANALISIS ESTIMASI SUDUT KEDATANGAN MENGGUNAKAN ALGORITMA ESPRIT PADA KOMUNIKASI MILLIMETER-WAVE UNTUK HYBRID BEAMFORMING
}

\author{
Egi Ari Wibowo', Heroe Wijanto², Iswahyudi Hidayat $^{3}$ \\ ${ }_{1,2,3}$ Fakultas Teknik Elektro, Universitas Telkom \\ 1egiwibowo13@gmail.com, ${ }^{2}$ heroe.wijanto@gmail.com, ${ }^{3}$ iswahyudi.hidayat@gmail.com
}

\begin{abstract}
Abstrak
Beberapa tahun belakangan ini, pertumbuhan traffic komunikasi wireless semakin meningkat pesat, hal ini menyebabkan ketersedian pita frekuensi semakin menipis. Cara untuk mengatasinya adalah dengan memanfaatkan pita frekuensi tinggi yaitu pada band millimeter-wave (mm-wave). Banyaknya antena yang digunakan pada teknologi mm-wave untuk mengatasi pathloss yang besar, akan teetapi dapat mengakibatkan kompleksitas yang tinggi pada sisi hardware jika menggunakan digital beamforming, karena satu RF chain terhubung dengan satu antena. Hybrid beamforming digunakan untuk meminimalisir penggunaan RF chain, sehingga kompleksitas pada sisi hardware menurun. Pada penelitian kali ini, telah dilakukan analisis algoritma ESPRIT pada hybrid beamforming untuk meningkatkan performansi sistem dalam hal penentuan posisi dan lokasi dari user atau sering disebut estimasi DOA yang nantinya akan digunakan dalam proses beamforming. Dari penelitian yang dilakukan, hasilnya adalah semakin banyak antena, RF chain, dan semakin besar nilai SNR yang digunakan maka akurasi algoritma ESPRIT dalam melakukan estimasi DOA akan semakin tinggi. Sedangkan jika semakin banyak sudut datang maka akurasinya akan semakin menurun. Hasil akurasi terbaik terjadi saat menggunakan jumlah antenna $8 \times 8$ dan RF chain sebanyak 6, dengan nilai $\Delta$ sebesar $0,00186^{\circ}$ dan nilai BER sebesar $5,7 \times 10^{-6}$.
\end{abstract}

Kata Kunci : mm-wave, hybrid beamforming, DOA, ESPRIT

Abstract

In recent years, the growth of wireless communication traffic has been increasing rapidly, causing the availability of the frequency bands to be low. The way to overcome this is by utilizing high frequency bands in millimeter-wave (mm-wave) band. The number of antennas used in mm-wave technology to overcome large path loss. However, high complexity on the hardware side if using digital beamforming, since one RF chain is connected to one antenna. Hybrid beamforming is used to minimize the use of RF chain, so the complexity on the hardware side decreases. In this research, ESPRIT algorithm analysis on hybrid beamforming has been done to improve system performance in terms of positioning and location of user or often called DOA estimation which will be used in beamforming process. From the research conducted, the result is more and more antenna, RF chain, and the bigger SNR value is used then the accuracy of ESPRIT algorithm in doing DOA estimation will be higher. Meanwhile, if more angles come then the accuracy will decrease. The best accuracy results occur when using the number of $8 \times 8$ antennas and $R F$ chains by 6 , with a value of $\Delta$ of $0.00186{ }^{\circ}$ and a BER value of $5,7 \times 10^{-6}$.

Keywords: mm-wave, hybrid beamforming, DOA, ESPRIT

\section{Pendahuluan}

Pertumbuhan komunikasi wireless meningkat pesat, hal ini menyebabkan ketersediaan pita frekuensi semakin menipis karena sudah digunakan untuk beberapa teknologi. Sehingga tidak ada kanal frekuensi yang tersisa untuk teknologi komunikasi wireless pada masa depan. Cara untuk mengatasinya adalah dengan memanfaatkan frekuensi tinggi yaitu pada band millimeter wave (mm-wave) yang memiliki rentang frekuensi $30-300 \mathrm{GHz}$ [1]. Akan tetapi penggunaan spektrum mm-wave akan menyababkan pathloss yang besar $[1,2]$.
Antena array yang banyak digunakan untuk mengatasi masalah pathloss yang besar. Tapi, banyaknya antena yang digunakan akan menyebabkan kompleksitas yang tinggi pada sisi hardware jika menggunakan sistem digital beamforming [3,4]. Karena pada digital beamforming, jumlah RF Chain yang dibutuhkan sama dengan jumlah antena yang digunakan.

Untuk mengurangi kompleksitas pada sisi hardware dengan menggabungkan antara analog beamforming dengan digital beamforming atau sering disebut dengan hybrid beamforming [3].

Pada penelitian kali ini, penulis akan meneliti 


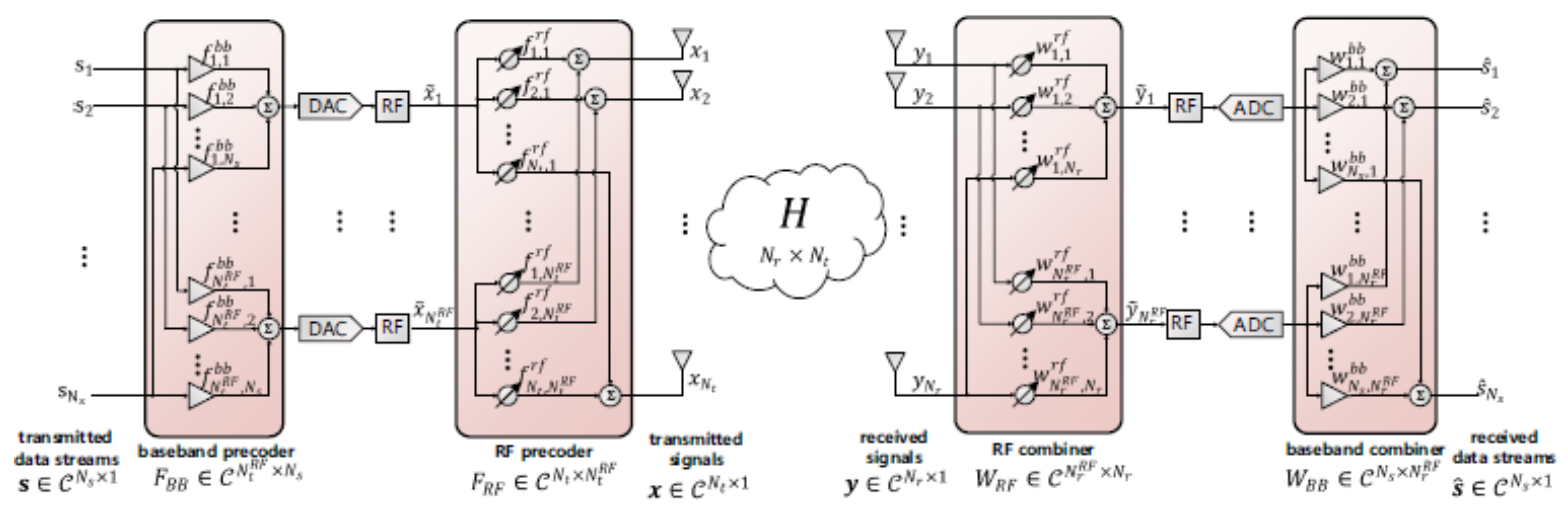

Gambar 1. Blok Diagram Sistem Hybrid Beamforming

tentang estimasi sudut kedatangan pada sistem hybrid beamforming menggunakan algoritma ESPRIT (Estimation of Signal Parameters Via Rotational Invariance Techniques). Algoritma ESPRIT merupakan salah satu algoritma yang memanfaatkan teknik subspace. Teknik subspace melakukan estimasi sudut kedatangan sinyal dengan memanfaatkan struktur eigen dan melakukan pemisahan antara noise subspace dan signal subspace [5,6]. Kelebihan dari ESPRIT sendiri adalah resolusinya tinggi artinya kemampuan untuk membedakan antara user dengan interferensinya tinggi dan kompleksitas komputasi rendah. Pada penelitian sebelumnya yang dilakukan Ramlond Anggito mengenai estimasi algoritma ESPRIT tanpa menggunakan sistem beamforming [5]. Girim Kwon meneliti tentang jumlah RF Chain yang optimal pada arsitektur hybrid beamforming [3]. Pada kesempatan kali ini, penulis akan meneliti tentang estimasi sudut menggunakan algoritma ESPRIT pada sistem hybrid beamforming.

\section{Dasar Teori}

\subsection{Millimeter-wave}

Millimeter-wave (mm-wave) band yang memiliki rentang frekuensi dari $30-300 \mathrm{GHz}$ (sering disebut sebagai EHF) semakin banyak yang melirik untuk digunakan pada komunikasi seluler yang akan datang. Karena pada frekuensi dibawah 3 $\mathrm{GHz}$ sudah banyak digunakan oleh teknologi lain. Selain belum banyak ditempati oleh teknologi yang lain, pada spektrum frekuensi mm-wave juga memiliki bandwidth yang lebar dan data rate yang tinggi sehingga sangat cocok untuk diaplikasikan pada sistem komunikasi dimasa depan yang direncanakan memiliki kecepatan data yang tinggi sampai 50 Gbps [7].

Untuk merencanakan penggunaan spektrum frekuensi mm-wave ini harus memeperhitungkan karakteristik propagasi sinyal radio pada rentang frekuensi ini. Karakteristik propagasi $m m$-wave mencangkup free space propagation dan efek dari berbagai macam faktor secara fisik.

$$
L_{F S L(d B)}=92,4+20 \log f+20 \log R
$$

\subsection{Hybrid Beamforming}

Hybrid beamforming merupakan gabungan dari digital beamforming dan analog beamforming [3]. Pada komunikasi mm-wave tidak dapat menggunakan digital beamforming dikarenakan satu RF Chain terhubung dengan satu antena, sedangkan pada komunikasi mm-wave dapat menggunakan banyak antena sehingga RF Chain yang digunakan banyak juga dan mengakibatkan cost yang besar. Sedangkan pada analog beamforming satu RF Chain terhubung dengan banyak antena, tapi tidak mendukung multistream. Untuk mengatasi kekurangan pada digital dan analog beamforming, hybrid beamforming menggabungkan kedua arsitektur tersebut. Tujuannya untuk menghasilkan transmisi yang efisien dengan menggunakan hardware yang sedikit (khususnya RF Chain). Untuk lebih jelasnya bisa dilihat blok diagram dari arsitektur hybrid beamforming pada Gambar 1 .

Dari blok diagram pada Gambar 1, sinyal yang diterima pada sisi receiver dapat dirumuskan sebagai berikut.

$$
\begin{gathered}
y=\sqrt{\rho} H x+n \\
H=\sqrt{\frac{N_{t} N_{r}}{L}} \sum_{l=1}^{L} \alpha_{l} A_{r} A_{t}^{H}
\end{gathered}
$$

Variabel y adalah sinyal yang diterima, $x$ adalah sinyal yang dikirim, $\rho$ adalah daya terima rata-rata, $n$ adalah noise gaussian, dan $H$ adalah fading propagation channel. Dimana $N_{t}$ dan $N_{r}$ adalah jumlah antena pada transmitter dan receiver, $\alpha_{1}$ adalah complex gain dari path ke-1, $A_{r}$ adalah steering vektor dari sisi receiver dan $A_{t}$ adalah steering vektor dari sisi transmitter.

$$
A_{r}=\frac{1}{\sqrt{N_{r}}}\left(1, e^{j \frac{2 \pi}{\lambda} d \sin (\theta)}, \ldots, e^{j \frac{2 \pi}{\lambda}\left(N_{r}-1\right) d \sin (\theta)}\right)^{H}
$$

Variabel $\lambda$ adalah panjang gelombang, $d$ adalah spacing elemen antena, dan $\theta$ adalah Angle of Arrival (AoA). 


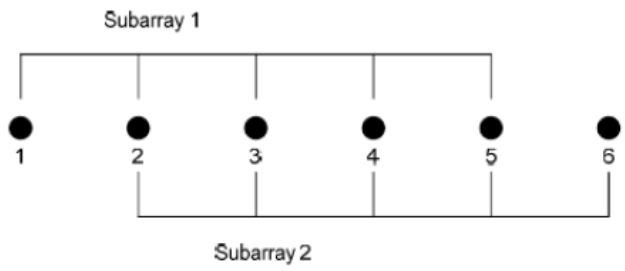

Gambar 2. Dua Sub-array dengan $\mathrm{L}=6$ Elemen Antena [5]

\subsection{ESPRIT}

Pada skema ESPRIT (Estimation of Signal Parameters Via Rotational Invariance Techniques) tidak melakukan scanning sudut melainkan memanfaatkan sifat rotational invariant dari susunan antena. Sifat rotational invariant memerlukan susunan array antena yang dapat dibagi menjadi dua sub-array yang salah satu sub-array adalah versi tergeser spasial dari sub-array lainnya. Untuk lebih jelasnya bisa lihat Gambar 2.

Pergeseran linier secara spasial ini menghasilkan persamaan sinyal terima antara subarray pertama dan sub-array kedua terhubung secara matematis, sehingga estimasi arah kedatangan sinyal dapat dihitung secara rumus tanpa perlu menggunakan scanning sudut. Berikut ini beberapa tahapan untuk estimasi arah kedatangan sinyal dengan algoritma ESPRIT.

1. Hitung matriks Covariance $R_{x x}$ dari vektor sinyal datang $x(n)$ dengan rumus berikut ini.

$$
R_{x x}=E\left\{X . X^{H}\right\}=\frac{1}{N} X X^{H}
$$

2. Hitung dekomposisi Eigen dari $R_{x x}$

$$
R_{x x}=U \sum U^{H}
$$

3. Partisi vektor Eigen $U$ menjadi sinyal subspace dan noise subspace menggunakan Eigen thresholding

$$
\begin{aligned}
& U_{s} \approx \lambda>0.5 * \frac{\operatorname{sum}(\lambda)}{\operatorname{SNR}} \\
& U_{n} \approx \lambda<0.5 * \frac{\operatorname{sum}(\lambda)}{\operatorname{SNR}}
\end{aligned}
$$

Dimana $U_{s}=$ signal subspace dan $U_{n}=$ noise subspace.

4. Partisi sinyal subspace menjadi dua subarray, sinyal subspace sub-array-1 $\left(U_{s 1}\right)$ dan sub-array-2 $\left(U_{s 2}\right)$. Selanjutnya hitung matriks rotation invariant menggunakan persamaan berikut.

$$
\Psi=\left(U_{s 1}^{H} \cdot U_{s 1}\right)^{-1} U_{s 1}^{H} \cdot U_{s 2}
$$

5. Untuk mencari estimasi sudut kedatangan dapat menggunakan persamaan berikut.

$$
\theta_{m}=\sin ^{-1} \frac{\lambda_{m}}{2 \pi \frac{d}{\lambda_{o p}}}, m=1, \ldots, M
$$

Dimana $\lambda_{\mathrm{m}}$ menyatakan nilai eigen value ke- $m$ dari matriks $\Psi$, sedangkan $\lambda_{o p}$ menyatakan panjang gelombang.

\section{Model dan Sistem}

Pada penelitian kali ini sistem transmisi hybrid beamforming dirancang seperti pemodelan pada Gambar 3 pada sisi transmitter dan Gambar 4 pada sisi receiver. Dimana sebelumnya blok sistem telah disisipi oleh blok ESPRIT untuk melakukan estimasi sudut kedatangan. Selanjutnya sistem akan dianalisis pada kondisi kanal rayleigh dan spesifikasi yang digunakan sesuai pada Tabel 1.

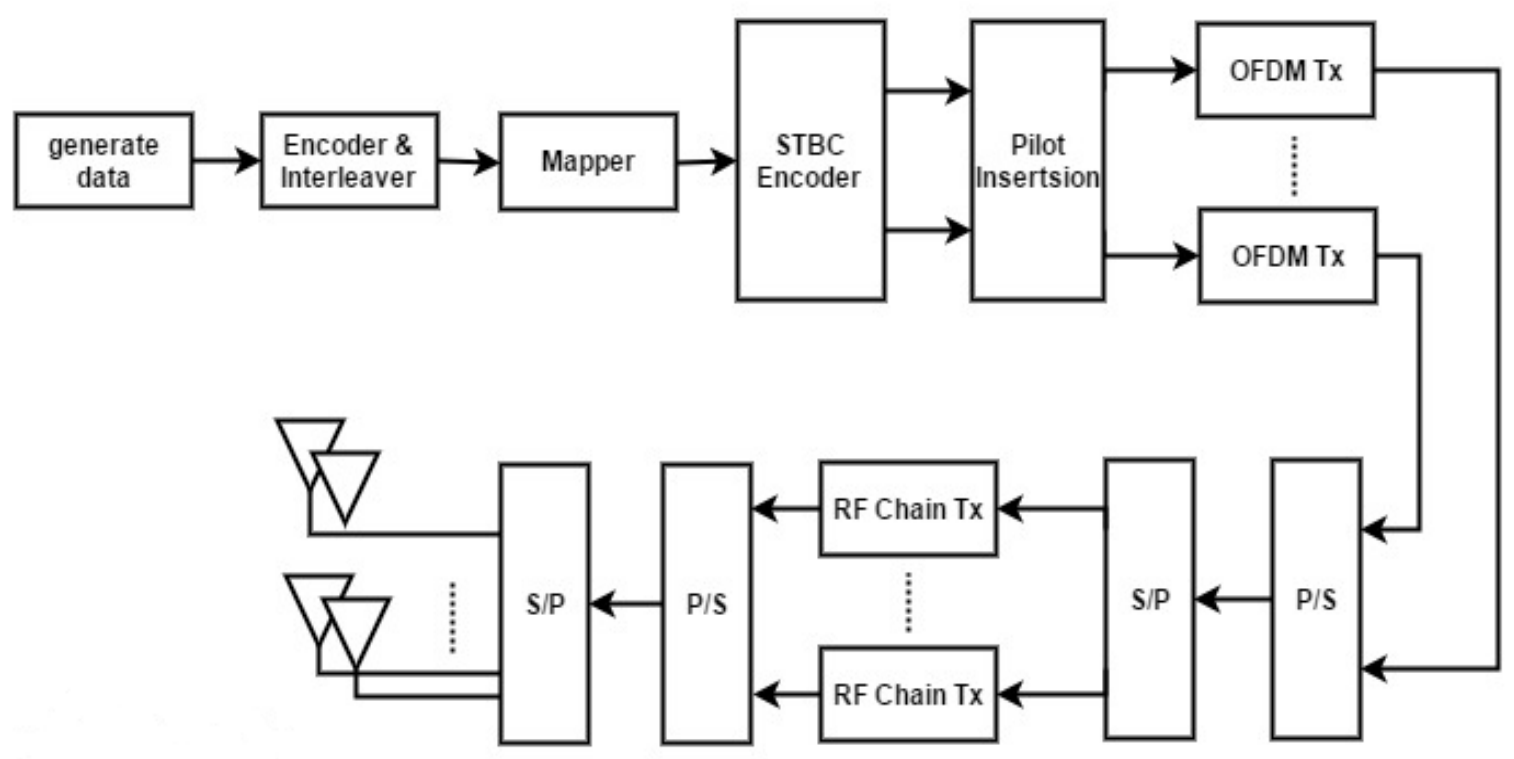

Gambar 3. Diagram Blok Sistem Hybrid Beamforming Sisi Transmitter 


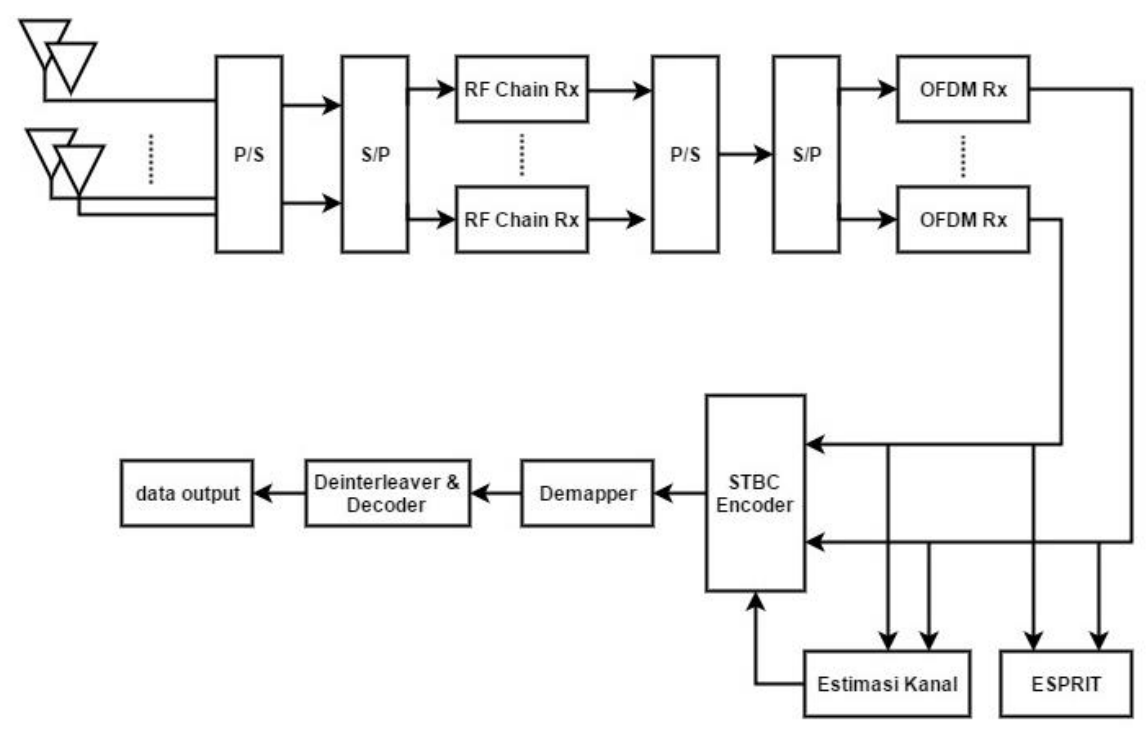

Gambar 4. Diagram Blok Sistem Hybrid Beamforming Sisi Receiver

Tabel 1. Spesifikasi Parameter Simulasi Sistem

\begin{tabular}{|c|c|}
\hline Parameter Simulasi & Spesifikasi \\
\hline Carrier frequency & $28 \mathrm{GHz}$ \\
\hline Bandwidth & $800 \mathrm{MHz}$ \\
\hline Modulation & $64 \mathrm{QAM}$ \\
\hline Coding & Convolutional code, rate $1 / 2$ \\
\hline Antena Tx \& Rx & $4,8(\mathrm{ULA})$ \\
\hline FFT size & 1024 \\
\hline Subcarrier spacing & $0.78 \mathrm{MHz}$ \\
\hline Periode simbol & $1.28 \mu \mathrm{s}$ \\
\hline Periode cyclic prefixt & $0.16 \mu \mathrm{s}$ \\
\hline Durasi simbol OFDM & $1.44 \mu \mathrm{s}$ \\
\hline
\end{tabular}

\section{Analisa Hasil Simulasi}

\subsection{Performansi Sistem Hybrid Beamforming}

Untuk melihat performansi sistem hybrid beamforming, dilakukan simulasi dengan dua parameter, yaitu jumlah antena pada sisi transmitter $\left(N_{T}\right)$ dan sisi receiver $\left(N_{R}\right)$, serta jumlah RF chain $\left(N_{R F}\right)$. Hasil simulasi akan membandingkan nilai BER terhadap $\mathrm{Eb} / \mathrm{No}$.

\subsubsection{Pengaruh Jumlah Antena terhadap Kinerja Sistem Hybrid Beamforming}

Percobaan kali ini dilakukan dengan sistem hybrid beamforming menggunakan RF chain $\left(N_{R F}\right.$ sebesar 2) pada sisi transmitter dan sisi receiver, serta jumlah antena pada sisi transmitter $\left(N_{T}\right.$ sebesar 4 dan 8) dan pada receiver ( $N_{R}$ sebesar 4 dan $8)$. Hasil dari percobaan kali ini dapat dilihat dari grafik BER terhadap Eb/ No yang ditunjukkan oleh Gambar 4. Percobaan kali ini dilakukan dengan tujuan membandingkan kinerja sistem hybrid beamforming saat menggunakan jumlah antena pada sisi transmitter dan receiver sebanyak empat elemen dan saat jumlah antena pada sisi transmitter dan receiver sebanyak delapan elemen.

Dari Gambar 5(a) menunjukkan grafik BER terhadap Eb / No. Dimana besar kecilnya nilai BER menandakan kemampuan suatu sistem komunikasi untuk mengirim dan menerima bit dengan baik. Semakin kecil nilai BER maka semakin kecil tingkat kesalahan pendeteksian bit yang dikirim yang berarti semakin baik kinerja sistem tersebut.

Hasil dari percobaan yang ditunjukkan pada Gambar 5(a) menunjukkan bahwa kinerja hybrid beamforming saat menggunakan jumlah antena pada sisi transmitter $\left(N_{T}=8\right)$ dan jumlah antena pada sisi receiver $\left(N_{R}=8\right)$ memiliki performansi yang lebih baik dari sistem hybrid beamforming saat menggunakan jumlah antena pada sisi transmitter ( $\left.N_{T}=4\right)$ dan jumlah antena pada sisi receiver $\left(N_{R}=\right.$ 4). Dimana untuk mencapai nilai BER sebesar $10^{-3}$ sistem hybrid beamforming dengan menggunakan antena $\left(N_{T}=4\right)$ dan $\left(N_{R}=4\right)$ membutuhkan $E b / N o$ sebesar $20 \mathrm{~dB}$. Sedangkan pada sistem hybrid beamforming dengan antena $\left(N_{T}=8\right)$ dan ( $\left.N_{R}=8\right)$ membutuhkan Eb/No sebesar $12 \mathrm{~dB}$. Sehingga dapat disimpulkan sistem dengan $\left(N_{T}=8\right)$ dan $\left(N_{R}=8\right)$ memiliki performansi yang lebih baik dari pada sistem dengan $\left(N_{T}=4\right)$ dan $\left(N_{R}=4\right)$, dengan perbaikan sistem sebesar $8 \mathrm{~dB}$.

\subsubsection{Pengaruh RF Chain terhadap Kinerja Sistem Hybrid Beamforming}

Percobaan kali ini, dilakukan dengan tujuan membandingkan pengaruh RF chain pada sistem hybrid beamforming. dimana pada percobaan kali ini digunakan jumlah RF chain yang berbeda-beda pada saat menggunakan jumlah antena pada sisi transmitter maupun receiver sebesar 8. Saat menggunakan jumlah antena sebesar 8 elemen pada 

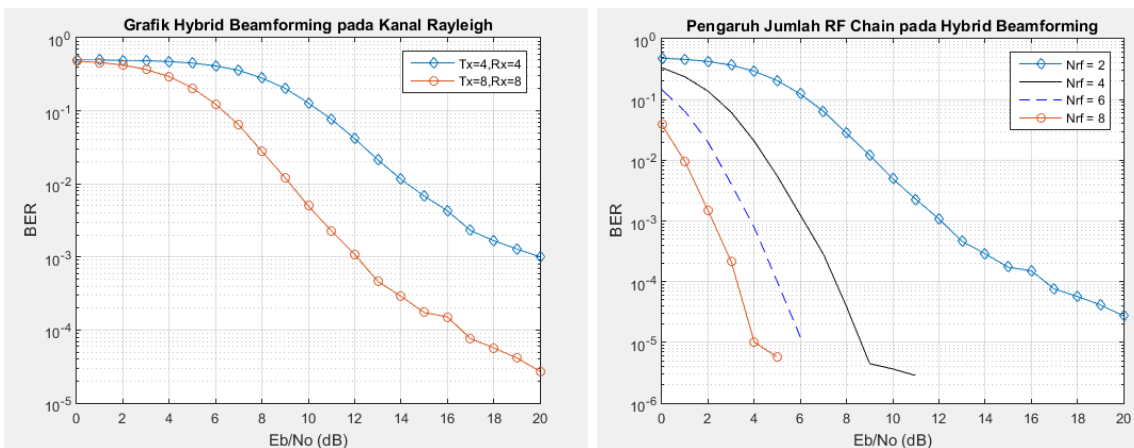

Gambar 5. (a) Grafik Pengaruh Jumlah Antena pada Sistem Hybrid Beamforming dengan $N_{R F}=2$

(b) Pengaruh Jumlah RF Chain pada Sistem Hybrid beamforming saat $N_{T}=8$ dan $N_{R}=8$

Tabel 2. Pengaruh SNR terhadap Akurasi Algoritma ESPRIT

\begin{tabular}{|c|c|c|}
\hline SNR & $\begin{array}{c}\text { jumlah sudut } \\
\text { terdeteksi }\end{array}$ & $\Delta\left({ }^{\circ}\right)$ \\
\hline 0 & 1 & 31,84446696 \\
\hline 5 & 2 & 20,34241236 \\
\hline 10 & 3 & 0,003935203 \\
\hline 15 & 3 & 0,002422745 \\
\hline 20 & 3 & 0,001580771 \\
\hline 25 & 3 & 0,000971094 \\
\hline 30 & 3 & 0,000316893 \\
\hline
\end{tabular}

transmitter maupun receiver, menggunakan $\mathrm{RF}$ chain $\left(N_{R F}\right.$ sebesar 2, 4, 6, dan 8).

Hasil dari simulasi yang ditunjukkan pada Gambar 5(b) menunjukkan bahwa untuk mencapai BER $10^{-4}$ sistem hybrid beamforming saat menggunakan $N_{R F}$ sebesar 2 membutuhkan $E b / N o$ sekitar $17 \mathrm{~dB}$, saat menggunakan $N_{R F}$ sebesar 4 membutuhkan $E b / N o$ sekitar $8 \mathrm{~dB}$, saat menggunakan $N_{R F}$ sebesar 6 membutuhkan $E b / N o$ sekitar $5 \mathrm{~dB}$, sedangkan saat menggunakan $N_{R F}$ sebesar 8 membutuhkan $E b / N o$ sekitar $4 \mathrm{~dB}$. Sehingga dapat dikatakan semakin banyak RF chain yang digunakan maka performansi sistem akan semakin baik, dengan performansi terbaik pada sistem hybrid beamforming terjadi pada saat menggunakan $N_{R F}$ sebesar 6 .

\subsection{Akurasi Algoritma ESPRIT pada Sistem Hybrid Beamforming}

Akurasi akan memberikan tingkat ketepatan algoritma dalam mendeteksi sudut datang. Hal ini dilakukan dengan memperoleh selisih antara sudut datang sebenarnya $\left(\theta_{i n}\right)$ dengan sudut hasil estimasi $\left(\theta_{\text {out }}\right)$ yang dapat disimbolkan dengan $(\Delta)$. Semakin kecil selisihnya, maka semakin tinggi akurasinya.

\subsubsection{Pengaruh Jumlah Antena terhadap Akurasi Algoritma ESPRIT}

Berikut ini merupakan hasil percobaan pengaruh jumlah antena terhadap akurasi algoritma

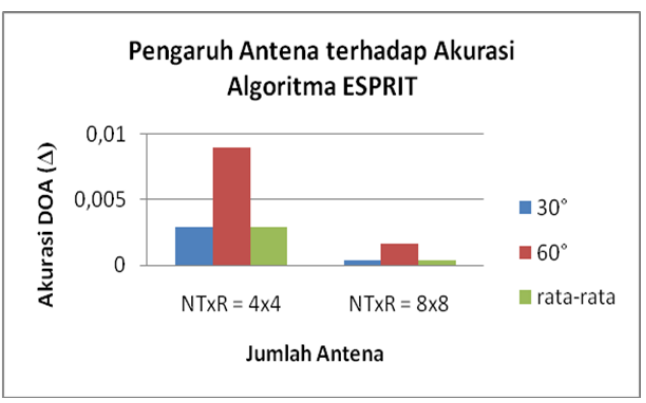

Gambar 6. Pengaruh Antena terhadap Akurasi Algoritma ESPRIT

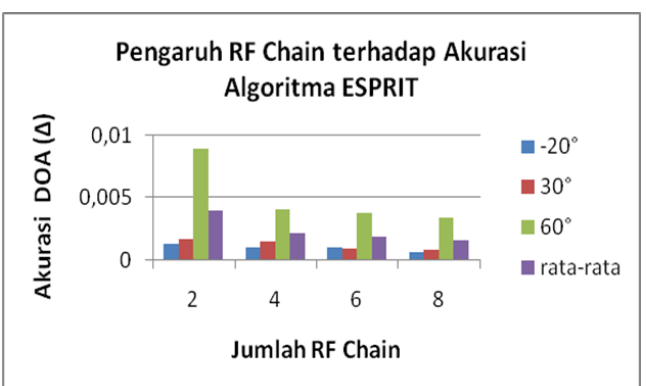

Gambar 7. Pengaruh RF Chain terhadap Akurasi Algoritma ESPRIT

ESPRIT dalam melakukan estimasi sudut datang pada sistem hybrid beamforming, dengan parameterparameter yang terlibat didalamnya antara lain; jumlah sinyal datang $(M=2)$, jumlah RF Chain ( $N_{R F}=2$ ), $\mathrm{SNR}=15 \mathrm{~dB}$, dan selisih sudut datang sebenarnya terhadap sudut hasil estimasi $(\Delta)$.

Dapat dilihat pada Gambar 6 pada sudut $60^{\circ}$ selisih antara sudut datang dan sudut estimasi $(\Delta)$ lebih besar dari pada sudut $30^{\circ}$. Hal ini disebabkan karena path gain pada sudut 60 bernilai $-1 \mathrm{~dB}$ lebih kecil dari path gain pada sudut 30 yang bernilai 0 dB. Sedangkan bertambahnya jumlah antena pada sistem hybrid beamforming, maka akurasi algoritma ESPRIT dalam melakukan estimasi sudut datang akan semakin tinggi. Hal ini dapat dilihat lebih jelas dari selisih sudut datang sebenarnya terhadap sudut estimasi $(\Delta)$. Dimana semakin kecil nilai $\Delta$ maka tingkat akurasi estimasi DOA semakin tinggi, begitu pula sebaliknya. Yang artinya akurasi terbaik terjadi 
saat menggunakan jumlah antena $\left(N_{T}=8\right)$ dan $\left(N_{R}\right.$ $=8$ ) dengan nilai rata-rata $\Delta$ sebesar $0,00033^{\circ}$.

\subsubsection{Pengaruh RF Chain terhadap Akurasi Algoritma ESPRIT}

Berikut ini merupakan hasil percobaan pengaruh jumlah RF chain terhadap akurasi algoritma ESPRIT dalam melakukan estimasi sudut datang pada sistem hybrid beamforming, dengan parameter-parameter yang terlibat didalamnya antara lain; jumlah sinyal datang $(M=3)$, jumlah antena $\left(N_{T}=8\right)$ dan $\left(N_{R}=8\right)$, SNR $=15 \mathrm{~dB}$, dan selisih sudut datang sebenarnya terhadap sudut hasil estimasi $(\Delta)$.

Dari hasil yang dapat dilihat pada Gambar 7, dengan bertambahnya jumlah RF Chain, maka akurasi algoritma ESPRIT dalam melakukan estimasi sudut datang akan semakin tinggi. Dari hasil percobaan, akurasi dilihat dari nilai $\Delta$, jika nilai ratarata $\Delta$ semakin kecil maka akurasi semakin tinggi, begitu juga sebaliknya. Pada saat $N_{R F}=2$ nilai ratarata $\Delta$ sebesar $0,00394^{\circ}$, saat $N_{R F}=4$ nilai rata-rata $\Delta$ sebesar $0,00211^{\circ}$, saat $N_{R F}=6$ nilai rata-rata $\Delta$ sebesar $0,00186^{\circ}$, dan saat $N_{R F}=8$ nilai rata-rata $\Delta$ sebesar $0,00157^{\circ}$. akurasi tertinggi pada estimasi sudut kedatangan menggunakan algoritma ESPRIT terjadi pada saat $N_{R F}=8$ (sistem digital beamforming). Sedangkan, akurasi tertinggi penggunaan algoritma ESPRIT pada sistem hybrid beamforming terjadi pada saat $N_{R F}=6$ dan selisih rata-rata $\Delta$ antara sistem hybrid beamforming ( $N_{R F}$ $=6$ ) dengan sistem digital beamforming sama dengan $0,00029^{\circ}$.

\subsubsection{Pengaruh SNR terhadap Akurasi Algoritma ESPRIT}

Berikut ini merupakan hasil percobaan pengaruh SNR terhadap akurasi algoritma ESPRIT dalam melakukan estimasi sudut datang pada sistem hybrid beamforming, dengan parameter-parameter yang terlibat didalamnya antara lain; jumlah sinyal datang ( $M=3)$, jumlah antena $\left(N_{T}=8\right)$ dan $\left(N_{R}=\right.$ 8), $N_{R F}=4$, dan selisih sudut datang sebenarnya terhadap sudut hasil estimasi $(\Delta)$.

Dari Tabel 2, ketiga sudut akan terdeteksi semua saat nilai SNR lebih dari $10 \mathrm{~dB}$. Sedangkan saat SNR sebesar $0 \mathrm{~dB}$, jumlah sudut yang terdeteksi hanya satu, dan pada saat SNR sebesar $5 \mathrm{~dB}$, jumlah sudut yang terdeteksi hanya dua. Sehingga nilai ratarata $\Delta$ saat $\mathrm{SNR} \geq 10 \mathrm{~dB}$ akan bernilai lebih kecil dari pada saat $\mathrm{SNR}=0 \mathrm{~dB}$ dan $\mathrm{SNR}=5 \mathrm{~dB}$. Hal ini disebabkan, semakin besar nilai SNR artinya perbandingan daya antara sinyal dan noise semakin jauh, sehingga lebih didominasi sinyal dari pada noise. Hal ini mengakibatkan proses thresholding yaitu pemisahan antara sinyal subspace dan noise subspace akan lebih baik.
Tabel 3. Pengaruh Jumlah Sudut terhadap Akurasi Algoritma ESPRIT

\begin{tabular}{|c|c|c|}
\hline $\begin{array}{c}\text { Jumlah sudut } \\
(M)\end{array}$ & $\begin{array}{c}\text { Jumlah sudut } \\
\text { terdeteksi }\end{array}$ & $\Delta\left(^{\circ}\right)$ \\
\hline 1 & 1 & 0,001037117 \\
\hline 2 & 2 & 0,001619909 \\
\hline 3 & 3 & 0,00211775 \\
\hline 4 & 4 & 0,002686902 \\
\hline 5 & 4 & 19,19078212 \\
\hline 6 & 4 & 26,38666852 \\
\hline
\end{tabular}

Sehingga dapat disimpulkan bertambahnya SNR dapat meningkatkan akurasi algoritma ESPRIT dalam melakukan estimasi sudut datang. Dengan akurasi tertinggi terjadi pada saat nilai $\mathrm{SNR}=30$ dengan rata-rata $\Delta$ sebesar $0,000316893^{\circ}$ dan akurasi terburuk terjadi pada saat $\mathrm{SNR}=0$ dengan rata-rata $\Delta$ sebesar $31,84446696^{\circ}$.

\subsubsection{Pengaruh Jumlah Sudut Datang terhadap Akurasi Algoritma ESPRIT}

Berikut ini merupakan hasil percobaan pengaruh jumlah sudut datang terhadap akurasi algoritma ESPRIT dalam melakukan estimasi sudut datang pada sistem hybrid beamforming, dengan parameter jumlah antena $\left(N_{T}=8\right)$ dan $\left(N_{R}=8\right), N_{\mathrm{RF}}$ $=4, \mathrm{SNR}=15 \mathrm{~dB}$, dan selisih sudut datang sebenarnya terhadap sudut hasil estimasi $(\Delta)$.

Dari Tabel 3, banyaknya sudut datang dapat mempengaruhi jumlah sudut yang terdeteksi. Saat jumlah sudut datang kurang dari atau sama dengan empat $(M \leq 4)$, maka algoritma ESPRIT pada sistem hybrid beamforming dapat mendeteksi semua sudut datang. Tetapi saat jumlah sudut datang lebih dari empat $(M>4)$, sistem tidak bisa mendeteksi semua sudut datang. Bisa dilihat pada Tabel 3 saat jumlah sudut datang 5 dan 6 , sudut datang yang terdeteksi pada sistem hybrid beamforming hanya 4 saja. Hal ini disebabkan dari penggunaan jumlah antena pada sisi receiver, pada algoritma ESPRIT jumlah antena yang baik untuk mendeteksi semua sudut datang harus dua kali lebih besar dari jumlah sudut datang $\left(N_{R}>2 M\right)$. Sehingga saat menggunakan antena $N_{R}=8$, jumlah sudut maksimum yang dapat terdeteksi adalah 4 .

Dari hasil percobaan, akurasi tertinggi terjadi pada saat jumlah sudut ( $M=1)$ dengan rata-rata $\Delta$ $0,001037117^{\circ}$ dan akurasi terburuk terjadi pada saat jumlah sudut ( $M=6$ ) dengan rata-rata $\Delta$ sebesar $26,38666852^{\circ}$

\section{Kesimpulan}

Dari hasil simulasi yang dilakukan dapat dikatakan bahwa penambahan jumlah antena pada sisi pengirim dan penerima dalam sistem hybrid beamforming dapat meningkatkan kinerja sistem pada kanal rayleigh. Dan semakin banyak RF chain yang digunakan maka, kinerja sistem hybrid 
beamforming akan semakin baik yang artinya kinerja digital beamforming lebih baik dari hybrid beamforming karena memiliki RF chain yang lebih banyak. Namun semakin besar jumlah RF chain dan jumlah antena yang digunakan berbanding lurus dengan kompleksitas sistem serta dapat mengakibatkan cost yang besar jika diimplementasikan.

Penambahan nilai SNR akan mempengarui akurasi algoritma ESPRIT dalam melakukan estimasi sudut datang pada sistem hybrid beamforming. Semakin besar nilai SNR maka akurasi algoritma ESPRIT akan semakin besar. Pada algoritma ESPRIT akan lebih baik jika SNR bernilai lebih dari $10 \mathrm{~dB}$.

Jumlah RF chain $\left(N_{R F}\right)$ akan mempengaruhi akurasi algoritma ESPRIT dalam melakukan estimasi sudut datang. Semakin besar nilai $N_{R F}$ maka akurasi algoritma ESPRIT akan semakin meningkat, dapat dilihat pada gambar 5(b). Yang artinya akurasi sistem digital beamforming lebih baik dari pada sistem hybrid beamforming. Namun peningkatan akurasi yang terjadi sangat kecil, hal ini bisa dilihat dari selisih rata-rata $\Delta$ yang terjadi antara digital beamforming $\left(N_{R F}=8\right)$ dengan hybrid beamforming ( $N_{R F}=6$ ) yang memiliki nilai sebesar $0,00028615^{\circ}$.

Semakin besar jumlah sudut datang $(M)$, maka akurasi algoritma ESPRIT pada sistem hybrid beamforming akan semakin menurun. Akurasi algoritma ESPRIT pada sistem hybrid beamforming akan baik jika jumlah sudut datang $M \leq N_{T x R} / 2$.

\section{DAFTAR PUSTAKA}

[1] Ma, Zheng, et al. "Key techniques for $5 \mathrm{G}$ wireless communications: network architecture, physical layer, and MAC layer perspectives." Science China Information Sciences 58.4 (2015): 1-20.

[2] Roh, Wonil, et al. "Millimeter-wave beamforming as an enabling technology for $5 \mathrm{G}$ cellular communications: theoretical feasibility and prototype results."IEEE Communications Magazine 52.2 (2014): 106-113.

[3] Kwon, Girim, et al. "Design of millimeter wave hybrid beamforming systems." 2014 IEEE 80th Vehicular Technology Conference (VTC2014Fall). IEEE, 2014.

[4] De Donno, Danilo, et al. "Hybrid analog-digital beam training for mmWave systems with lowresolution RF phase shifters." Communications Workshops (ICC), 2016 IEEE International Conference on. IEEE, 2016.

[5] Ramlond Anggito "Analisa dan Simulasi Esitimasi Sudut Kedatangan Menggunakan Algoritma Estimation of Signal Parametr via Rotational Invariance Techniques (ESPRIT) pada Wireless Mobile Communication", IT Telkom, Bandung, 2009.

[6] Chen, Zhizhang. "Introduction to Directional of Arrival Estimation”, Artech House, 2010.

[7] Michael Marcus and Bruno Pattan "Millimeter Wave Propagation: Spectrum Management Implications", IEEE Microwave Magazine, June 2005. 